\title{
The "spirit" of the old communion chants
}

\author{
ADRIAN SÎRBU \\ "George Enescu" National University of the Arts Iași \\ ROMANIA*
}

\begin{abstract}
Byzantine music is the chanted prayer of the Orthodox Church left to us as a spiritual legacy by the holy masters of hymnography and hymnology ever since the early centuries. This music serves a precise purpose, i.e. to enhance the mood of prayer and to lift man closer to God. The Holy Liturgy, the mystical centre and the reference point of a man's entire existence, represents man's private meeting and communion with Christ, and the moment of this meeting is steeped in an atmosphere of meditation and inwardness created by a series of ample, slow, and vocalization-rich chants, called koinonika. It is a moment of ultimate inner appeasement and preparation. Early composers managed to capture this meditation effect in their koinonika, both through their compositional techniques and, especially, through an inner state of grace. However, in the $19^{\text {th }}$ century, two phenomena became apparent: on the one hand, some of the new composers no longer succeeded in attaining the same ethos as the old masters, and, on the other hand (particularly from Ioan PopescuPasărea on), the music tastes of the time caused these ample chants to be replaced with simpler melodies, which, often, were even harmonized. This study has a threefold aim: first, it reasserts the fundamental role played by the koinonikon in the Holy Liturgy, by arguments that underline the ancientness of this practice as well as its survival in other Orthodox areas (such as Mount Athos and Greece). Second, the paper signals the publication, next year, of the first Romanian collection of koinonika signed by Byzantine and post-Byzantine composers $\left(13^{\text {th }}-19^{\text {th }}\right.$ centuries $)$. Third, our study aims to show that these ancient chants have a special ethos, representing melodic as well as aesthetic archetypes and, par excellence, the true Classicism of Byzantine melos.
\end{abstract}

Keywords: Byzantine, music, koinonikon, communion chants.

\section{Introduction}

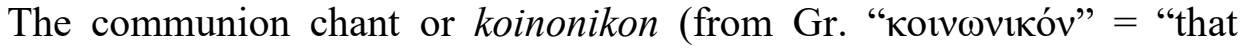
which is common") is usually a psalm verse chanted while the clergymen and the faithful receive the communion during the Holy Liturgy. It aims to create an atmosphere propitious to the soulful introspection of those who will commune with the Body and Blood of Jesus Christ.

In the Early Church, this moment was marked by the singing of a psalm (Troelsgård, 2002, p. 744), either in its entirety (such as Psalm 50/51 at Matins) or divided into verses, each sentence being followed by a koinonikon, i.e. the main verse (Foundoulis, 2009, p. 87) (such as the weekly or the feast

*adrian_sirbu2005@yahoo.com 


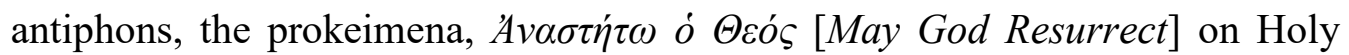
Saturday, etc. ${ }^{1}$ ) sung as a chorus.

The content of the koinonika was meant to induce the faithful to receive

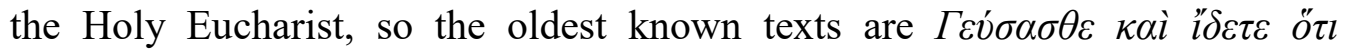

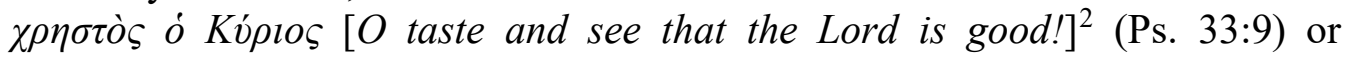

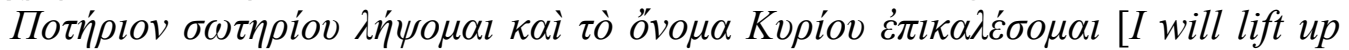
the cup of salvation and call on the name of the Lord $]^{3}$ (Ps. 115:4). They were sung during all the liturgies, regardless of the feast. Gradually, the texts grew more and more diverse, with themes that were directly linked to the type of feast at hand ${ }^{4}$. Besides the koinonika selected from the psalms, hymnography also records three verses from scriptural texts and two hymns (see the table below) .

Through this diversification of texts (after the $19^{\text {th }}$ century), the koinonika received the role of highlighting the theme of each feast. Thus, there may be Sunday, weekly, or feast koinonika, or chants for other feasts in the religious year (Cf. Barbu-Bucur, 1992), covering the entire interval allotted to communion (not only of the priests but of the faithful as well ${ }^{6}$ ).

\footnotetext{
${ }^{1}$ This historical evolution is used by the liturgist Ioannis Foundoulis as an argument to provide a solution to the church choirs who find it impossible to chant the koinonikon. The replacement variant supposes singing the original psalm, from which the text of the koinonikon has been extracted. When the extended chant cannot be sung, Foundoulis suggests returning to the tradition of singing the psalms in their entirety, stressing that "once more, people will learn the psalms and will feed on the biblical spiritual food that they provide" (Foundoulis, 2009, p. 88).

${ }^{2}$ Here and henceforth the English versions of the quoted psalm verses were taken from King James Version of the Bible after the use of the Orthodox Church (Asser, 2005).

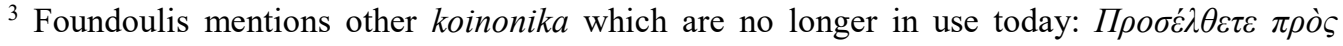

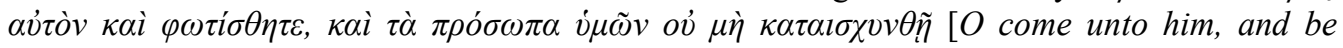

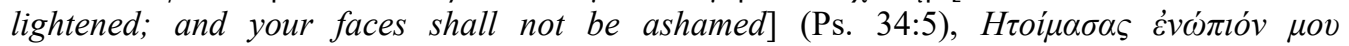

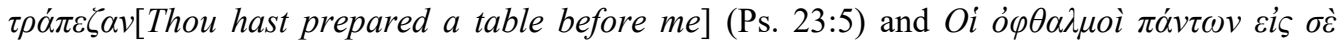

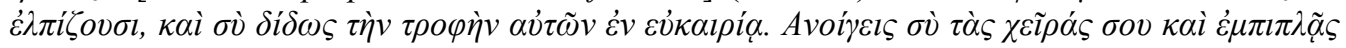

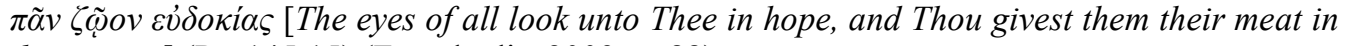
due season] (Ps. 145:15) (Foundoulis, 2009, p. 88).

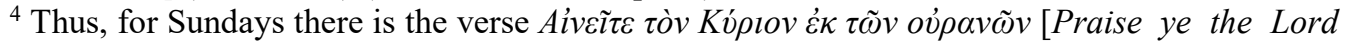
from the heavens] (Ps. 148:1), while for the beginning of the church year ( ${ }^{\text {st }}$ of September),

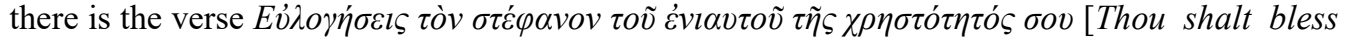
the crown of the year of Thy goodness] (Ps. 64:12) etc.

5 Christian Troelsgård mentions the existence in the $7^{\text {th }}$ century (in the Constantinople standard) of the troparion $\Pi \lambda \eta \rho \omega \theta \dot{\eta} \tau \omega \tau \grave{o} \sigma \tau \dot{o} \mu \alpha \dot{\eta} \mu \tilde{\omega} v$ [Let our mouths be filled] with the final part, Alleluia, playing the role of a koinonikon. Gradually, the psalm was probably reduced to a single verse (original chorus followed by Alleluia), while the troparion $\Pi \lambda \eta \rho \omega \theta \eta \dot{\tau} \tau \tau$ ò $\sigma \tau o ́ \mu \alpha$ $\dot{\eta} \mu \tilde{\omega} v$ was separated from it, becoming a chant programmed after the moment of the koinonikon (Troelsgård, 2002, p. 744).

${ }^{6}$ The great liturgist Ioannis Foundoulis points out to the erroneous practices in which the koinonikon is no longer chanted as a continuation of and during the moments when the believers receive the communion, emphasizing that this habit "overlooks the purpose of the Sacrament and ignores a cardinal aspect of the entire rite. Continuing the koinonikon is the only
} 
As early as the $9^{\text {th }}$ century, a complete koinonika repertoire for the great feasts in the church year is already available. Until the early $15^{\text {th }}$ century, the standard tradition records the presence of 22 texts which underlay the evolution and sedimentation of this genus (Gheorghiță, 2009, p. 15-18) ${ }^{7}$. The table below lists the koinonikon texts that are still used in current liturgical practice, structured by the moment when they are sung in the liturgy (Sunday, weekly and feast koinonika) as well as by their source texts (verses from psalms or hymns and other scriptural sources).

\section{Koinonikon texts in current liturgical practice}

\begin{tabular}{|c|c|c|c|c|}
\hline & Text in Romanian & Text in English & Text in Greek & Moment of celebration \\
\hline \multicolumn{5}{|c|}{ Sunday Koinonikon } \\
\hline 1 & $\begin{array}{l}\text { Lăudati pe Domnul } \\
\text { din ceruri. Aliluia. } \\
\text { Ps. 148:1 }\end{array}$ & $\begin{array}{l}\text { Praise ye the Lord from } \\
\text { the heavens. Alliluia }\end{array}$ & 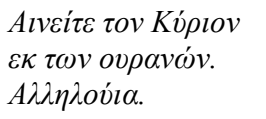 & $\begin{array}{l}\text { Sundays and Forefeasts, } \\
\text { Mid-Pentecost, Lazarus } \\
\text { Sunday, Holy Saturday }\end{array}$ \\
\hline \multicolumn{5}{|c|}{ Weekly Koinonika } \\
\hline 2 & $\begin{array}{l}\text { Cel ce face pe } \\
\text { ingerii Săi duhuri } \\
\text { şi pe slugile Sale } \\
\text { pară de foc. } \\
\text { Aliluia. Ps. 103:5 }\end{array}$ & $\begin{array}{l}\text { Who maketh His angels } \\
\text { spirits, and His } \\
\text { ministers a flaming } \\
\text { fire. }\end{array}$ & 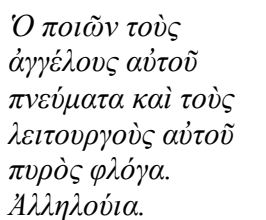 & $\begin{array}{l}\text { Mondays and Feast of } \\
\text { the Holy Angels }\end{array}$ \\
\hline 3 & $\begin{array}{l}\text { Întru pomenire } \\
\text { veşnică va fi } \\
\text { dreptul. Aliluia. } \\
\text { Ps. 111:6 }\end{array}$ & $\begin{array}{l}\text { The righteous shall be } \\
\text { in everlasting } \\
\text { remembrance. Alliluia. }\end{array}$ & 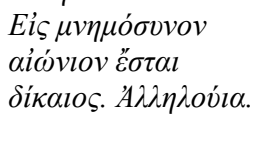 & $\begin{array}{l}\text { Tuesdays, the Nativity } \\
\text { of St. John the Baptist, } \\
\text { Hierarchs, Righteous, } \\
\text { Indiction (1 September) }\end{array}$ \\
\hline 4 & $\begin{array}{l}\text { Paharul mântuirii } \\
\text { voi lua şi numele } \\
\text { Domnului voi } \\
\text { chema. Aliluia. Ps. } \\
\text { 115:4 }\end{array}$ & $\begin{array}{l}\text { I will take the cup of } \\
\text { salvation, and call } \\
\text { upon the name of the } \\
\text { Lord. Alliluia. }\end{array}$ & 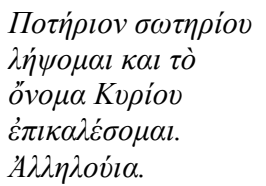 & $\begin{array}{l}\text { Wednesdays and on the } \\
\text { feasts of the Holy } \\
\text { Virgin, Akathistos, } \\
\text { Saturday }\end{array}$ \\
\hline 5 & $\begin{array}{l}\text { In tot pământul a } \\
\text { ieşit vestirea lor şi } \\
\text { la marginile lumii } \\
\text { cuvintele lor. } \\
\text { Aliluia. Ps. 18:4 }\end{array}$ & $\begin{array}{l}\text { Their sound is gone out } \\
\text { into all the earth, and } \\
\text { their words to } \\
\text { the ends of the world. } \\
\text { Alliluia. }\end{array}$ & 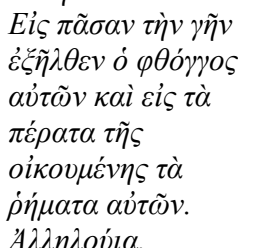 & $\begin{array}{l}\text { Thursdays and on } \\
\text { Apostles Feasts }\end{array}$ \\
\hline 6 & $\begin{array}{l}\text { Mântuire ai făcut } \\
\text { în mijlocul } \\
\text { pământului. } \\
\text { Aliluia. Ps. } 73: 13\end{array}$ & $\begin{array}{l}\text { He hath worked } \\
\text { salvation } \\
\text { in the midst of the } \\
\text { earth. Alliluia. }\end{array}$ & 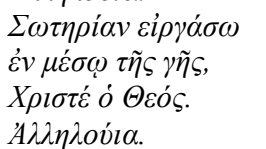 & Fridays \\
\hline
\end{tabular}

correct solution that also supports tradition", concludes the researcher (Foundoulis, 2009, pp. 84-85).

${ }^{7}$ Another list of koinonika may be found in Dimitri E. Conomos (1985a, pp. 48-51). 


\begin{tabular}{|c|c|c|c|c|}
\hline 7 & $\begin{array}{l}\text { Fericitit sunt cei pe } \\
\text { care } i \text {-ai ales şi } i \text { - } \\
\text { ai primit Doamne, } \\
\text { şi pomenirea lor în } \\
\text { neam și în neam. } \\
\text { Aliluia. Ps. } 64: 4\end{array}$ & $\begin{array}{l}\text { Blessed is he whom } \\
\text { Thou hast chosen, and } \\
\text { taken unto Thee; } \\
\text { he shall dwell in Thy } \\
\text { courts. Alliluia. }\end{array}$ & 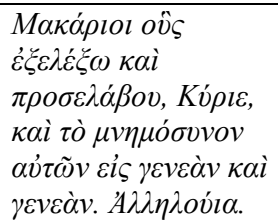 & $\begin{array}{l}\text { Saturdays and when } \\
\text { remembering the dead }\end{array}$ \\
\hline \multicolumn{5}{|c|}{ Feast Koinonika (I) with texts from the psalms ${ }^{8}$} \\
\hline 8 & $\begin{array}{l}\text { Binecuvânta-vei } \\
\text { cununa anului } \\
\text { bunătătaii Tale, } \\
\text { Doamne. Aliluia. } \\
\text { Ps. } 64: 12\end{array}$ & $\begin{array}{l}\text { Thou shalt bless the } \\
\text { crown of the year of } \\
\text { Thy goodness. Alliluia. }\end{array}$ & 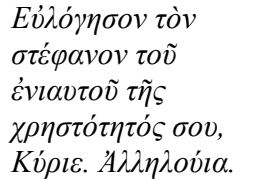 & Indiction (1 September) \\
\hline 9 & $\begin{array}{l}\text { Insemnatu-s-a } \\
\text { peste noi lumina } \\
\text { feței Tale, } \\
\text { Doamne. Aliluia. } \\
\text { Ps. 4:6 }\end{array}$ & $\begin{array}{l}\text { The light of Thy } \\
\text { countenance is signed } \\
\text { upon us, O Lord. } \\
\text { Alliluia. }\end{array}$ & 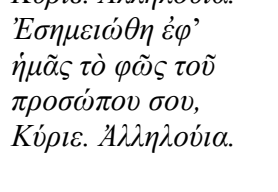 & $\begin{array}{l}\text { The Elevation of the } \\
\text { Holy Cross (14 } \\
\text { September), Sunday of } \\
\text { the Holy Cross (Third } \\
\text { Sunday of Lent) }\end{array}$ \\
\hline 10 & $\begin{array}{l}\text { Mântuire trimis-a } \\
\text { Domnul poporului } \\
\text { Său, în pace. } \\
\text { Aliluia. Ps. } 110: 9\end{array}$ & $\begin{array}{l}\text { He sent redemption to } \\
\text { His people. Alliluia. }\end{array}$ & 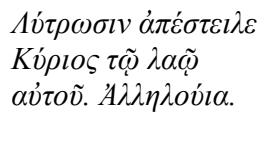 & $\begin{array}{l}\text { The Nativity of Our } \\
\text { Lord and Saviour }\end{array}$ \\
\hline 11 & $\begin{array}{l}\text { A ales Domnul } \\
\text { Sionul, l-a dorit } \\
\text { ca locuință Lui. } \\
\text { Aliluia. Ps. 131:13 }\end{array}$ & $\begin{array}{l}\text { For the Lord hath } \\
\text { chosen Zion, He hath } \\
\text { chosen it for His } \\
\text { habitation. Alliluia. }\end{array}$ & 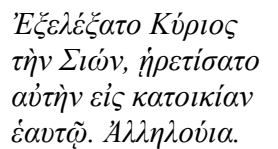 & The Annunciation \\
\hline 12 & $\begin{array}{l}\text { Din gura pruncilor } \\
\text { și a celor ce sug, } \\
\text { săvârșit-ai laudă. } \\
\text { Aliluia. Ps. } 8: 3\end{array}$ & $\begin{array}{l}\text { Out of the mouths of } \\
\text { babes and sucklings } \\
\text { hast Thou perfected } \\
\text { praise. Alliluia. }\end{array}$ & 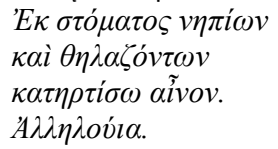 & Lazarus Saturday \\
\hline 13 & $\begin{array}{l}\text { Bine este cuvântat } \\
\text { cel ce vine întru } \\
\text { numele Domnului. } \\
\text { Aliluia.Ps. } 117: 26\end{array}$ & $\begin{array}{l}\text { Blessed is he that } \\
\text { cometh in the name of } \\
\text { the Lord. Alliluia. }\end{array}$ & 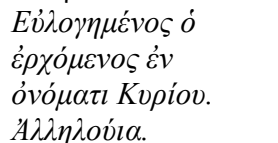 & Palm Sunday \\
\hline 14 & $\begin{array}{l}\text { Sculatu-S-a ca } \\
\text { dintr-un somn } \\
\text { Domnul, și a înviat } \\
\text { mântuindu-ne pre } \\
\text { noi. Aliluia. Ps. } \\
\text { 77:65 }\end{array}$ & $\begin{array}{l}\text { Then the Lord awaked } \\
\text { as one out of sleep, and } \\
\text { saved us. Alliluia. }\end{array}$ & 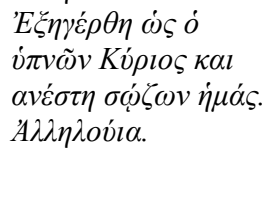 & Holy Saturday \\
\hline 15 & $\begin{array}{l}\text { Laudă Ierusalime } \\
\text { pe Domnul, laudă } \\
\text { pe Dumnezeul tău } \\
\text { Sioane. Aliluia. Ps. } \\
\text { 147:1 }\end{array}$ & $\begin{array}{l}\text { Praise the Lord, } O \\
\text { Jerusalem; praise thy } \\
\text { God, O Zion. Alliluia. }\end{array}$ & 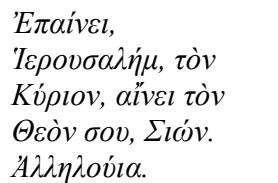 & Thomas Sunday \\
\hline 16 & $\begin{array}{l}\text { Suitu-s-a } \\
\text { Dumnezeu întru } \\
\text { strigare, Domnul } \\
\text { in glas de } \\
\text { trâmbiță. Aliluia. } \\
\text { Ps. 46:5 }\end{array}$ & $\begin{array}{l}\text { God is gone up with } \\
\text { jubilation, the Lord } \\
\text { with the sound of the } \\
\text { trumpet. Alliluia. }\end{array}$ & 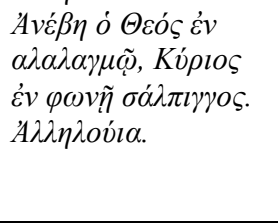 & Holy Ascension \\
\hline
\end{tabular}

\footnotetext{
${ }^{8}$ The list of communion chants presented by Gheorghiță (2009, p. 18-22) also includes Sfințit-a lăcaşul Său cel preaînalt [Lord, I have loved the beauty of Thy house, and the place where Thy glory dwelleth] (Ps. 25:8), which is chanted upon the anniversary of the Great Church of Constantinople (23 December).
} 


\begin{tabular}{|c|c|c|c|c|}
\hline 17 & $\begin{array}{l}\text { Duhul Tău Cel } \\
\text { Bun, să mă } \\
\text { povătuiască la } \\
\text { pământul } \\
\text { dreptății. Ps. } \\
142: 10 \\
\text { Duhul Tău Cel } \\
\text { Bun nu-L lua de } \\
\text { la noi, rugămu- } \\
\text { ne, Iubitorule de } \\
\text { oameni. Aliluia. }\end{array}$ & $\begin{array}{l}\text { Thy good Spirit shall } \\
\text { lead me into the land } \\
\text { of uprightness. } \\
\text { Alliluia. }\end{array}$ & 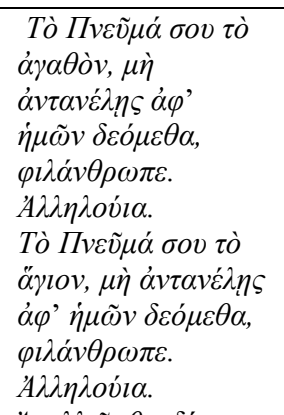 & Holy Pentecost Sunday \\
\hline 18 & $\begin{array}{l}\text { Bucurați-vă } \\
\text { drepților în } \\
\text { Domnul. Aliluia. } \\
\text { Ps. } 32: 1\end{array}$ & $\begin{array}{l}\text { Rejoice in the Lord, } O \\
\text { ye righteous. Alliluia. }\end{array}$ & 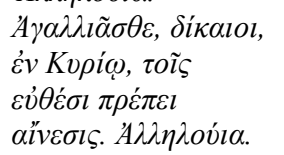 & $\begin{array}{l}\text { Martyrs, prophets, } \\
\text { Sunday of All Saints }\end{array}$ \\
\hline 19 & $\begin{array}{l}\text { Întru lumina slavei } \\
\text { fetei Tale, } \\
\text { Doamne, vom } \\
\text { umbla în veci. } \\
\text { Aliluia. } \text { Ps. 88:16- } \\
17\end{array}$ & $\begin{array}{l}\text { They shall walk, } O \\
\text { Lord, in the light of Thy } \\
\text { countenance, and } \\
\text { in Thy name shall they } \\
\text { rejoice all the day. } \\
\text { Alliluia. }\end{array}$ & 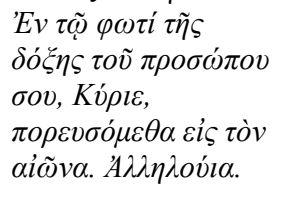 & The Transfiguration \\
\hline 20 & $\begin{array}{l}\text { Aduce-se-vor } \\
\text { Împăratului } \\
\text { fecioare în urma } \\
\text { ei, aduce-se-vor în } \\
\text { templul } \\
\text { Impăratului. } \\
\text { Aliluia. Ps } 44: 16- \\
18\end{array}$ & $\begin{array}{l}\text { The virgins that follow } \\
\text { her shall be brought } \\
\text { unto the king; } \\
\text { those that are near to } \\
\text { her shall be brought } \\
\text { unto thee. Alliluia. }\end{array}$ & 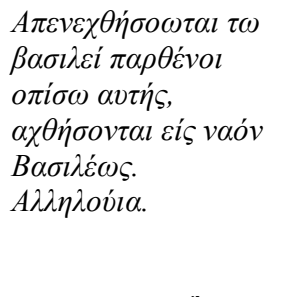 & $\begin{array}{l}\text { The Holy Mother's } \\
\text { Entrance into the } \\
\text { Temple (21 November) }\end{array}$ \\
\hline 21 & $\begin{array}{l}\text { Gustați și vedeți că } \\
\text { bun este Domnul. } \\
\text { Aliluia. Ps. } 33: 9\end{array}$ & $\begin{array}{l}\text { O taste and see that the } \\
\text { Lord is good. Alliluia. }\end{array}$ & 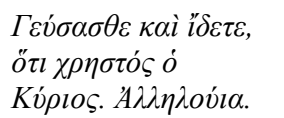 & $\begin{array}{l}\text { Divine Liturgy of the } \\
\text { Presanctified Gifts }\end{array}$ \\
\hline 22 & $\begin{array}{l}\text { Pomenirea } \\
\text { drepților cu laude } \\
\text { și pomenirea lor în } \\
\text { neam și în neam. } \\
\text { Aliluia. Ps. 101:13 }\end{array}$ & $\begin{array}{l}\text { But Thou, O Lord, } \\
\text { endurest for ever, and } \\
\text { Thy remembrance } \\
\text { from generation to } \\
\text { generation. Alliluia. }\end{array}$ & 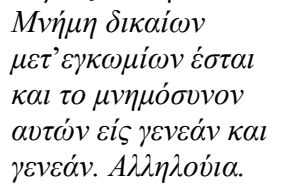 & $\begin{array}{l}\text { Remembrance of the } \\
\text { Dead, Beheading of St. } \\
\text { John the Baptist }\end{array}$ \\
\hline \multicolumn{5}{|c|}{ Feast Koinonika (II) from other scriptural texts or hymns } \\
\hline 23 & $\begin{array}{l}\text { Arătatu-s-a darul } \\
\text { lui Dumnezeu cel } \\
\text { mântuitor tuturor } \\
\text { oamenilor. Aliluia. } \\
\text { Titus2:11 }\end{array}$ & $\begin{array}{l}\text { For the grace of God } \\
\text { has appeared for the } \\
\text { salvation of all men. } \\
\text { Alliluia. }\end{array}$ & 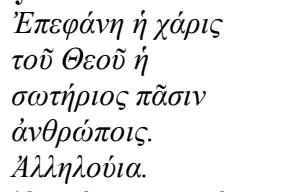 & $\begin{array}{l}\text { The Theophany of Our } \\
\text { Lord and Saviour Jesus } \\
\text { Christ }\end{array}$ \\
\hline 24 & $\begin{array}{l}\text { Cel ce mănâncă } \\
\text { Trupul Meu și bea } \\
\text { Sângele Meu, întru } \\
\text { Mine rămâne și Eu } \\
\text { întru dânsul, spus- } \\
\text { a Domnul. Aliluia. } \\
\text { John 6:56 }\end{array}$ & $\begin{array}{l}\text { He who eats my flesh } \\
\text { and drinks my blood } \\
\text { abides in me, and I in } \\
\text { him. Alliluia. }\end{array}$ & 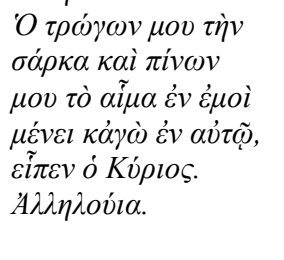 & Mid-Pentecost \\
\hline 25 & $\begin{array}{l}\text { Trupul lui Hristos } \\
\text { primiți și din } \\
\text { izvorul cel fără de } \\
\text { moarte gustați. } \\
\text { Aliluia.(hymn) }\end{array}$ & $\begin{array}{l}\text { Partake the body of } \\
\text { Christ and taste the } \\
\text { source of immortality. } \\
\text { Alliluia. }\end{array}$ & 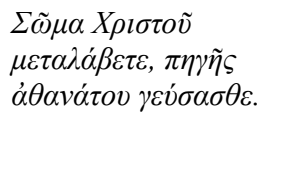 & Resurrection of Christ \\
\hline
\end{tabular}




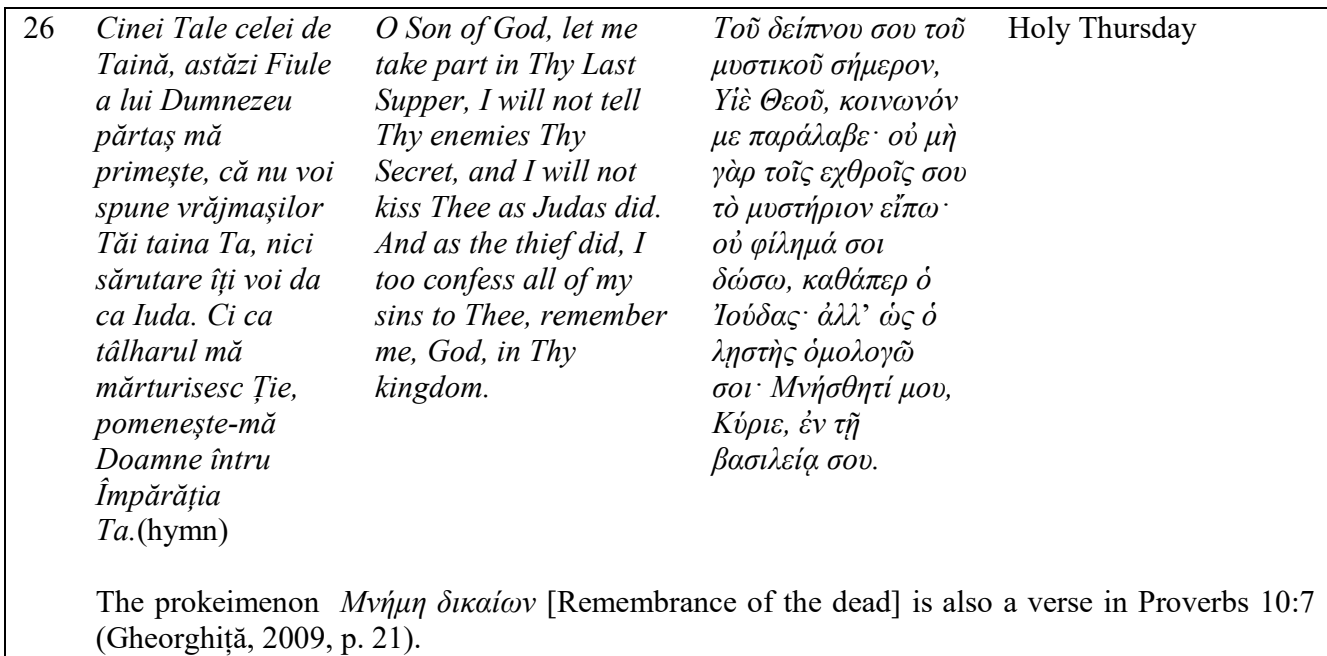

\section{Chourmouzios Chartophylax' exegesis work. The phenomenon of exegeseis}

As we may read from the study in the Greek edition, Chourmouzios Chartophylax' exegeseis work (archived in the series "Metochion of the Holy Sepulchre" from the Greek National Library) saved from oblivion an impressive repertoire of the old masters' works.

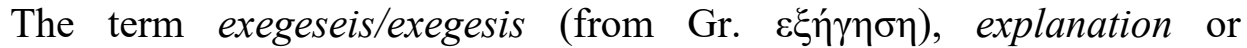
interpretation, designates the more analytical notation system (using mainly quantitative signs $^{9}$ ) that aimed to provide a more detailed record of the melody. The first accounts of exegeseis date from $1670^{10}$. The notation available at that time, i.e. late middle Byzantine notation, was a complex system in which psaltic signs could not be interpreted in isolation (as they are today), but only in context. Thus, the same notation fragment could be sung in different manners (melos) depending on several factors (voice, pitch, genre, form and style of singing, degree of celebratory mood, place, mode of interpretation choir or solo, etc. $)^{11}$. As a result, in 1670 (in ms. 1250, the Iviron Monastery), Balasios the Priest produced a more elaborate transcription of Ioannis Kladas'Trisagion in phthora nenano for the Funeral Service (see fig. 1), which is considered the first attempt at exegeseis.

\footnotetext{
${ }^{9}$ i.e. of black neumes, at the expense of the great hypostases (red neumes).

${ }^{10}$ In the early $16^{\text {th }}$ century, the work of Akakios Halkeópoulos left us several written accounts of musical exegeseis.

11 Taking all these factors into account, professor Giannou referred to the old notation as a „context sensitive notation”. See Maria Alexandru, Paleography Course III.
} 
Late middle Byzantine notation composition by Ioannis Kladas $\left(14^{\text {th }}-15^{\text {th }}\right.$ century $)$

The first account of exegesis - Balasios the Priest, 1670, exegetic middle Byzantine notation.

A more developed stage of exegesis - Petros the Peloponnesian (late $18^{\text {th }}$ century)

Exegesis in Chrysanthic notation Chourmouzios Chartophylax (early $19^{\text {th }}$ century)
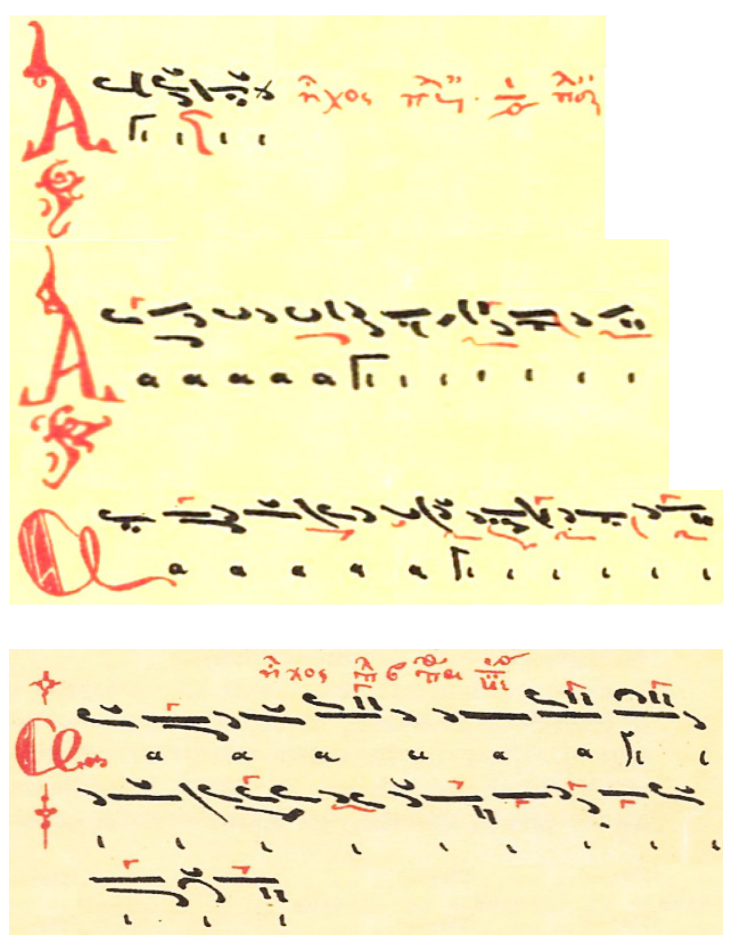

Fig. 1 Trisagion for the Funeral Service, illustrated in several ways, from original semiography to the last stage of exegesis

(Psachos, 1978, p. 68)

The complexity of exegeseis as a process that took into account all the aforementioned factors reveals the monumental nature of Chourmouzios Chartophylax's works. The old notation (see fig. 2), much more codified, was impossible to decipher in the absence of a direct connection to oral tradition.

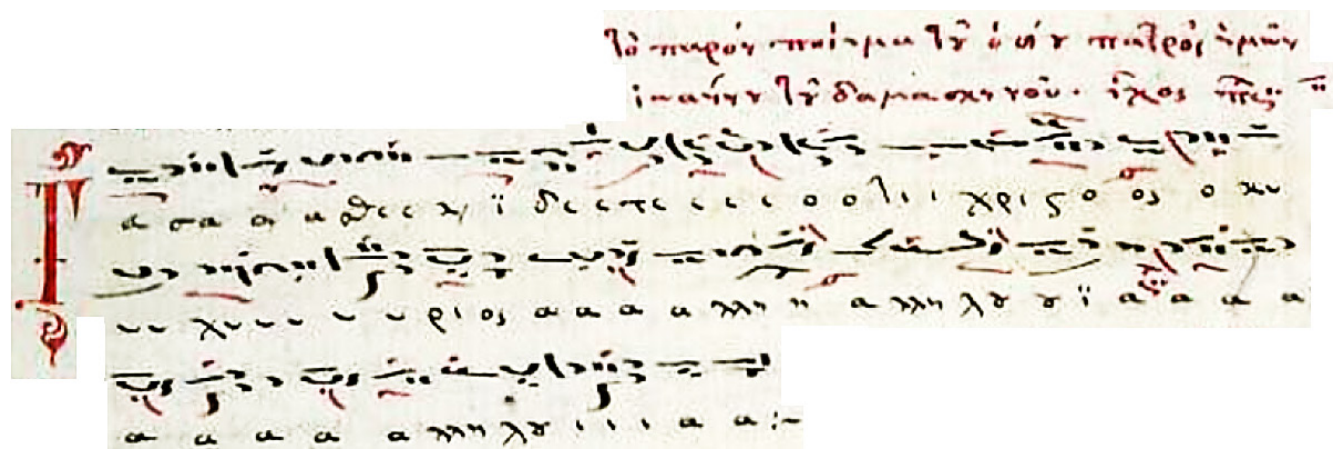

Fig. 2 The koinonikon $\Gamma \varepsilon v ́ \sigma \alpha \sigma \theta \varepsilon \kappa \alpha i ̀ ~ i ́ \delta \varepsilon \tau \varepsilon$ [O Taste and See], plagal of the Second, by St. John of Damascus (late middle Byzantine notation), in ms. BAR 27820, f. 256r. 
Chourmouzios Chartophylax' exegeses reveal the hidden beauty of the melodies underlying the theseis $^{12}$ of late middle Byzantine notation. As a matter of fact, these archetypal melodic formulas ground the entire compositional paradigm of psaltic art. Thus, music kept its formulaic nature, because semiography (no matter how analytical it might have become) remained a mnemotechnical graphic system whose decoding was inconceivable without the oral tradition.

\footnotetext{
${ }^{12}$ Thesis (from Gr. $\theta \dot{\varepsilon} \sigma \eta \varsigma$ ) is the term used in Psaltic Art to refer to the melodic formulas of each tone, which encompass the archetypal melodic units that underlie the structure of a psaltic melody. In middle Byzantine notation theseis are written synoptically (in a synthetic, summarizing manner) but in actual practice their interpretation is a complex, dynamic phenomenon that takes into account various factors (voice, pitch, genre, form and style of singing, degree of celebratory mood, genre, place, mode of interpretation - choir or solo, etc.). Manuel Chrysaphes (whose activity peaks from 1440 to 1463) emphasizes the complexity of interpreting the theseis based on compositional genres:

"Thesis means the union of signs which forms the melody. As in grammar the union of the twenty-four letters forms words in syllables, in the same way the signs of the sounds are united scientifically and form the melody. This then is called thesis. But, O my friend, do not think that the manner of the whole musical art and its practice is so simple and uniform that the composer of a kalophonic sticheron with appropriate theseis who does not adhere to the manner of the old sticheron can think that he has done that which he has written quite good and free from every condemnation - since, if what he has composed does not include the method of the old sticheron, it is not correct. Do not think that the performance is simple, but rather that is complex and of many forms. Know that the stichera and the oikoi differ greatly from each other according to their use and in other matters about which the art is concerned. For one kind of manner and practice pertains to the sticheron, another to the katanyktikon, another to the kratema, another to the megalynarion, another to the oikoi, another to the cherubikon and another to the alleluarion" (Conomos, 1985, pp. 42, 43). Below, an example of thesis (kylisma) exegesis, according to the manuscripts of Xeropotamou 357 and Docheiariou 389 (Stathis,
} 1998, p. 65):

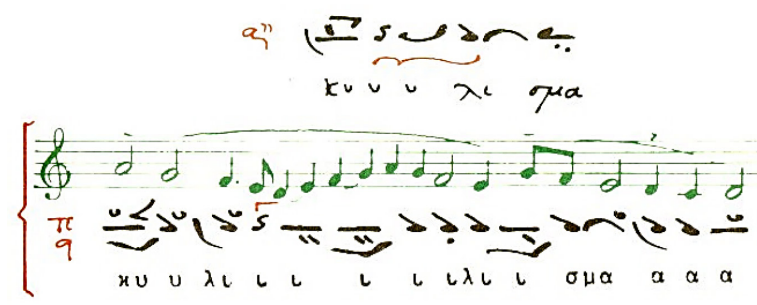




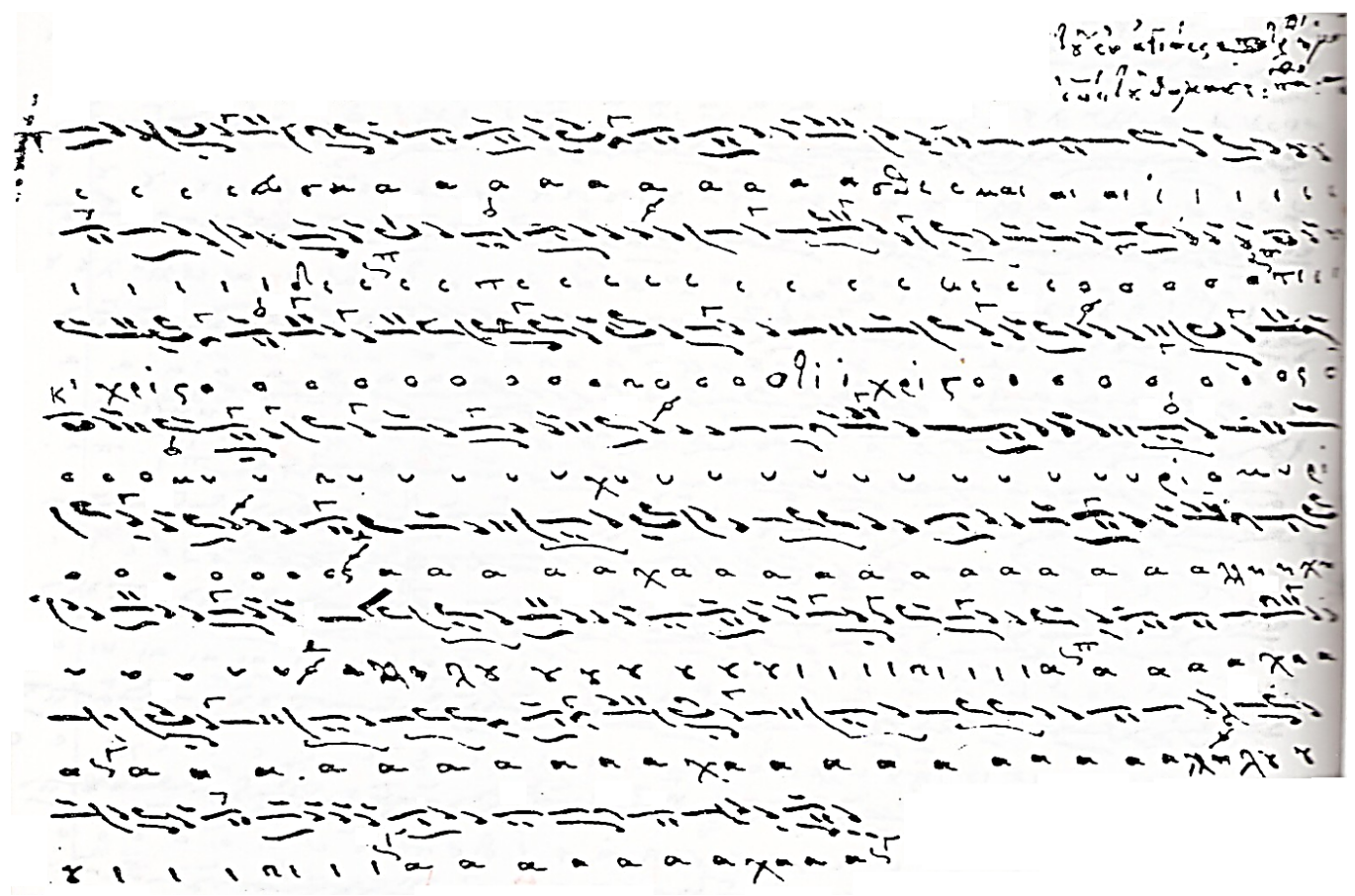

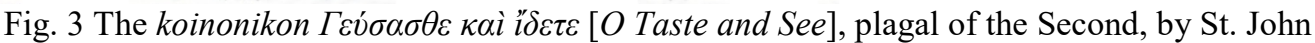
of Damascus transcribed by Chourmouzios Chartophylax in autographed Chrysanthic МПТ 705 , f. $221 \mathrm{v}$.

\section{On the "spirit" of the old chants}

There are very few writings on the compositional style of the old masters. In general, the works on this subject adopted a historical, biographic, or codicographic perspective, and offered few details on the style of each composer. In fact, a general stylistic analysis outlining the compositional traits of individual styles would require sound knowledge about each master's entire oeuvre, regardless of whether it encompasses exegetical or middle Byzantine notation works.

Macarie the Hieromonk is, without any doubt, one of the most illustrious figures in Byzantine music, an excellent master of all the psaltic repertoires (from the Anastasimatar [Anastasimatarion] to Irmologhion Calofonicon [Eirmologion Kalophonikon] or Papadichie [Papadike]), a "clasic" by definition, a restless promoter of classical authors and genuine psaltic style. Macarie also witnessed the entire process of reform taking place in the notation system during the early $19^{\text {th }}$ century and he supported the Romanianization of chants while preserving the "spirit" of the old, original, ones.

In the Preface to Irmologhion Catavasier [Eirmologion-Katabasies], the great Wallachian composer mentioned several valuable ideas that summarize 
his views on the way in which compositional style had evolved in time. Below, the fragment in its entirety ${ }^{13}$ :

"As to the binding of these holy chants, they were very deep in meaning, difficult and burdensome, and all of the succeeding creators, preserving the godliness of their forerunners, would leave behind their heavy and burdensome makings as well.

But then came Chrysaphes the New Protopsaltis and Balasios the Priest, who left their Teachings, pleasant and less burdensome, to the Holy Church.

And after them, his beatitude Petros the Sweet Bereketis made his makings even less taxing, even more adequate, sweeter and wonderful. He too, most reverend and holy, did not alter the meaning of the ways of the holy fathers. [...] And after his beatitude Petros the Sweet, Ioannis and Daniel, the protopsaltes of the Great Church of Christ, showed us the way to a leaner writing, creating new, exceedingly beautiful Teachings. It is only after them that we could distinguish the new chants from the old. But in all things, they too, in all their holiness, guarded the old as their most precious gift.

Then Petros the Lampadarios Peloponnesios, more gifted in the ways of writing ${ }^{14}$, a very clever and knowledgeable man in all Church matters and all things Persian ${ }^{15}$ as well, multiplied the new chants more than any other maistor; the differences between the old and new became great indeed.

And, following the ways of his writing, all his successors increased even more the easiness of their creations, and added even more outside elements in them ${ }^{16}$. However, with all the easiness effected by this way of writing, there was no founding, the scheme and its entirety could not be enclosed, and all that sweetness within was inappropriate.

So, looking at this with a philosopher's eyes, Chrysanthos of Madytos, Gregory the Protopsaltis and Chourmouzios Chartophylax of the Great Church of Christ $^{17},[\ldots]$ devised this new system (the New Method o.n.), enclosing it in immutable canons, alleviating it in all its ways, and philosophically including it among the scientific disciplines. And they reformed all of the books according to this system, those of the first holy fathers and those of the old and new masters too, without damaging in the slightest neither the melos of the new nor of the $o_{l d}^{18}$. To this day, God's gift has therefore watched over and guarded the holy chants of our Church and will forever keep them unaltered in the days to come" (Macarie Ieromonahul, 1823, pp. 7-9).

Macarie's thoughts allow us to draw the following conclusions:

- The ancient chants were deep in meaning, difficult and burdensome. As a result, they were not difficult as far as their melos was concerned but

\footnotetext{
${ }^{13}$ Our emphasis.

${ }^{14}$ Because he devised a more exegetical, analytical notation.

${ }^{15}$ Arabo-Persian musical culture.

${ }^{16}$ The analytical notation promoted by Petros the Peloponnesian was, for some, an open door for the insertion of melodies that did not belong to the genuine style.

${ }^{17}$ Ecumenical Patriarchy of Constantinople.

${ }^{18}$ Meaning that their exegeseis did not alter the melos of older chants.
} 
rather difficult to understand in their "deeper" meaning and accessible only to the initiated few, not only musically, but also spiritually.

- Chrysaphes the Protopsaltis and Balasios the Priest open a new compositional era, proposing a style that was more accessible (to their contemporaries) but preserving the "spirit" of the old works.

- As it is well known now, Petros Bereketis excels in large compositions, enriching the existing repertoire, with his exceptional talent, with works "more adequate, sweeter and wonderful", without straying, however, from the "meaning of the ways of the holy fathers".

- Ioannis and Daniel "guarded" the old chants "as their most precious gifts", but their compositions start to be distinguishable from the old ones. Here Macarie is likely to refer to the fact that the two introduced new theseis (melodic formulae) but without changing classical compositional structures and rules in the slightest.

- Being "clever" and "gifted", Petros the Peloponnesian enriched the psalter repertoire to a great extent, using a more analytical, more exegetical notation system (aiming to provide a more detailed account of the melos). This semiography allowed many composers to insert in the chants outside elements that disagreed with the old psaltic style.

- The three teachers, Chrysanthos, Chourmouzios and Gregory, laid the theoretical foundations of the new notation system (which is rooted in Petros the Peloponnesian's notation), defending through their exegeses and theoretical writings the "classicism" of Church music, the established theseis and a unitary style. Chourmouzios and Gregory's exegetical work constitutes a living proof of the unity of style gathering within the same crucible, unitary in its diversity, an entire host of masters, from John of Damascus to Nikephoros Ithikos, Ioannis Koukouzelis andPetros the Peloponnesian.

- Macarie adopts a very critical stance against the unwelcome infiltrations taking place in his time at the compositional and interpretive level. Beyond the great teacher's manifest for a much desired Romanianization of the chants from the Preface of the Irmologhion, his words should be a warning (just as valid today) against the risk of introducing in the Church practice chants that no longer adhere to the "deep meaning" and the profound experience of the "spirit" and "meaning" of the Holy Fathers, diverting the mind and soul of the faithful from the word to the melody and from the spirit to the voice.

Macarie the Hieromonk is not the first to have underlined the importance of preserving traditional compositional features in order to remain within the scope of authenticity. In his treatise, while discussing the composers who 
preceded him ${ }^{19}$, Manuel Chrysaphes shows how they had carefully followed the traditional line of their predecessors.

"Thus even in the kalophonic stichera the composers of these do not depart from their original melodies but follow them accurately, step by step, and retain them. Therefore, they take over some melodies unchanged from tradition and from the music thus preserved [...] and they all follow the path unaltered throughout the entire composition. The second composer always follows his predecessor and his successor follows him and, to put it simply, everyone retains the technique or the art. [...] We - if we do not wish to distort the truth and precision of our science - must act in this way, and no one would with justice reproach us for this action but rather would praise us" (Conomos, 1985b, pp. 45, 47).

There is, of course, an entire dynamic of psaltic tradition, innovating elements that manage to take hold when the genius of a composer such as St. Ioannis Koukouzelis is inspired enough to be original without changing the canons. As G.K. Angelinaras $(2009$, p. 69,70$)$ also shows, the great composers were very aware that any attempt at renewing traditional elements could only be grounded in the values inherited from the past, which endured and imposed themselves in time, thus acquiring universal prestige.

$$
* * *
$$

In recent years, the interest in researching, unearthing, and revaluing the chants of the great pre- $18^{\text {th }}$-century composers has considerably grown. Psalter music groups such as the Greek Byzantine Choir (conductor Lykourgos Angelopoulos) or the Maistors of Psaltic Art (conductor Gregorios Stathis) "lauched", in the last decades of the century past, a new approach to the psaltic repertoire, supported by manuscript research, score publishing, album recordings, radio and TV shows, etc.

Recently, access to the koinonika of the old teachers transcribed by Chourmouzios Chartophylax - see the series of autograph manuscripts from the Metochion of the Holy Sepulchre ("МПТ") in the Greek National Library have opened new lines of understanding, not only theoretical, but also practical - in the church choir loft -, of the classic formulaic structures present in these ancient compositions. For four years, together with the students majoring in Byzantine Music at the "George Enescu" National University of the Arts we have been able to sing the communion chants of the old masters $\left(13^{\text {th }}-18 \mathrm{t}^{\mathrm{h}}\right.$ century) during the Divine Liturgy owing to Chourmouzios' exegeses, a practice which resulted in an incurable "addiction" to the balanced and unitary

\footnotetext{
${ }^{19}$ Manuel refers here to Ioannis Koukouzelis, Aneotes, Nikiforos Ithikos, Ioannis Glykis and Ioannis Kladas.
} 
style of the old "makings". Their clear and logical musical form, their settled, tranquil style, the way in which the melody passes from a thesis to the next with no passages that stray from the formulaic structure - all these are features which homogenize stylistically, as a diachronic invariable, the entire legacy left by these great teachers.

Angelinaras seizes the old masters' depth of style and its diachronic, ecumenical and archetypal nature: "Analysing Manuel Chrysaphes' $\Sigma \tilde{\omega} \mu \alpha$ X comparing it with newer works for the same feast we see that Chrysaphes' piece is much richer and so diachronic that we feel it addresses all the Christian believers, from all times and places, and it envelops and represents all of them in a truly universal melody, while newer compositions are usually the result of a momentary, contextual, and often time-framed stroke of genius. I do not belittle all new creations, though. Each age has its good parts as well" (Angelinaras, 2009, p. 72).

It is precisely this classical style that Macarie tried to defend through his exegetical and editorial work, being fully aware of the threats to the process of chant Romanianization posed by the possibilities of analytical writing brought about by the New System and the Chrysanthic reform ${ }^{20}$. If not as early as Daniel and Ioannis, then undoubtedly with those who followed Petros Lampadarios, this style was increasingly endangered.

The formulaic nature of the old chants is not always preserved by the new compositions. Notation allows the insertion of melody lines that are difficult to identify with any classical thesis structure, and this, in fact, represents a deviation from the old and classical compositional concept.

Indeed, preserving these archetypal melodic formulae intact in these chants has a soothing, calming effect for the mind and soul, because the melody produces no surprises, does not use unknown, unpredictable elements that could divert attention from the text to the music. When classical theseis are at work, the mind recognizes throughout only unitary melodic structures, rests on them, and even anticipates and expects them - based on the traditional succession of theseis. Thus, the melodies remain a tranquil and fertile ground

\footnotetext{
${ }^{20}$ The 1814 Chrysanthic reform brings about a change of paradigm. Semiography is no longer using the large signs which represented, potentially, theseis whose execution (the melos) could vary considerably according to the context. Chrysanthic notation "dismantles" these large signs and imposes a "reference" exegesis by an analytical notation which does not focus on expression signs but, rather, uses vowel and time signs to produce - for the first time in history - a detailed account both of the way in which the melody progresses and of rhythmic subdivisions. The new notation has the advantage of reducing to a common denominator through Chourmouzios and Gregory's exegeses - the various ways of interpreting the theseis, but, on the flip side, there is only one melodic version that prevails, and other variants (from oral tradition) no longer match the Chrysanthic score which is now seen as a reference.
} 
for the internalization of prayer. The Holy Fathers worked wisely on this compositional element which protects the mind in and through prayer and does not hypnotize it with "surprising" melodies producing states of mind that are far from a reconciled, inward spirit.

The superiority of archetypal melodic formulae when compared with various innovations is directly and clearly emphasized by Angelinaras as well: "These archetypes hide an incomparable wealth of sensations and ethea, with their structures of a Dorian simplicity, with their greatness and strength that are able to express even the transcendental. [...] Archetypal forms thin down the senses, give shape to what is blurred, educate unruly feelings, avoid exaggeration and do not bother with useless details. The archetype is the cell generating new creative processes that enrich and perpetuate the tradition.

On the contrary, melodic processing shows a lack of creative drive, expressive meagreness, spiritual stagnation, and cultural regress. The attempt to study archetypes is not the result of retrograde attitudes. Returning to origins shows that modernity cannot isolate itself by limiting itself just to the present, but should instead turn to the past to learn how to prepare for the future.

We do not study the old chants so as to imitate them blindly, but so as to find the best way to show our inspiration. [...] This return does not mean giving up creative actions, but turning to the joy of creating and the thirst of renewal" (Angelinaras, 2009, p. 72).

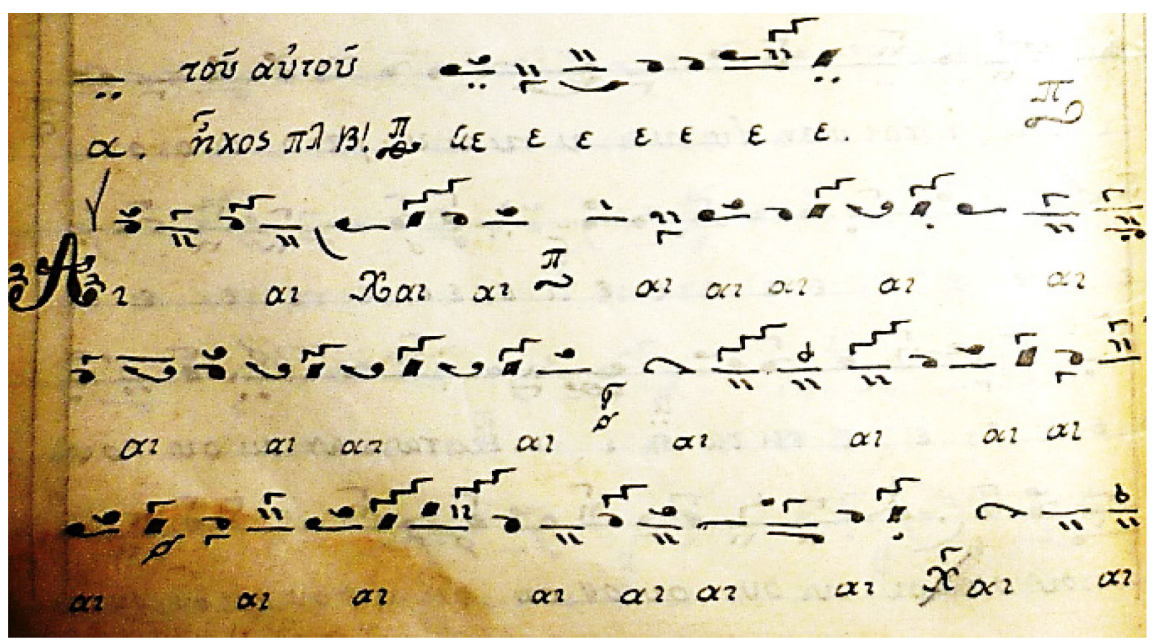

Fig. 4 Example of a melody written in a hyper analytical manner, where the time-

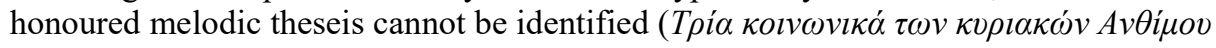

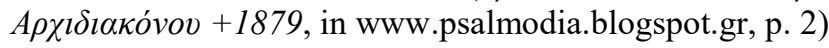

\section{The role of the Koinonikon in the liturgical context}

The liturgy is, par excellence, the central moment in the liturgical life of a community. All the services in a day converge towards this most uplifting 
moment, the union with Christ through the Eucharist, while the Sunday Liturgy, that of the Resurrection, is the culmination of the entire weekly cycle.

The Liturgy, the highest spiritual embodiment of the meeting between the human and the divine, is a collection of various forms of prayer, from thanksgiving to supplication and praise, all of them marked by the mystical element of the bread and wine turning into the Saviour's Body and Blood and the believers' communing with Him through the Eucharist. Thus, the liturgy becomes a communion, a koinonia, and this is why most of the choir's responses (which form a fixed repertoire, outside the cycle of the Octoechos) should also be chanted by all the faithful taking part in the service ${ }^{21}$. However, there are three jubilation moments, three pieces of musical "virtuosity", of melodic climax through which the inward experiences of the believers are transformed into instants of exaltation: the Trisagionhymn (the Sanctus), the Cherubic hymn and the Koinonikon (See Conomos, 1974 and Karagkounis, 2003). They are chants devoted par excellence to the psaltis, the specialist, because they require a great amount of vocal virtuosity. Just like the iconographers, the architects and the sculptors who devoted all of their best and their greatest artistic expressions to the Holy Church, the psaltes should spare no effort in expressing all of their best talents and gifts when singing the extended chants. The well-known protopsaltis Panagiotis Neochoritis stated in an interview that "it is in extended chants that the ethos of the modes is best experienced". Here, the mind descends to the heart, the soul calms down and rests, settles in this state marked by the ethos of sounds and begins resonating with the psaltes and the isokrates. It is the moment that prepares the great encounter of the Eucharist. Everything is suspended, the mind recollects and, even more, the prayer manages to transcend the words as the choir echoes the sounds of a kratima that seems to follow an ever ascending spiral. A mood of appeasement and exaltation is thus created, a mood that the old teachers knew how to use only for the spiritual purpose of prayer.

Wanting to find out what the specialists think of the importance of chanting the koinonikon, we asked father Filotheu Bălan from "Petru Vodă" Monastery why it is important for the communion chant not to be removed from the Divine Liturgy. His answer was revealing: "Because it has to do with the education of the spirit. Being supported by these extended formulae and this musical conception, prayer is much easier to internalize. The syntomosdromos is enticing you to join in the singing, but in the case of the

21 Liturgical chants are meant to keep a balance between a state of spiritual alertness

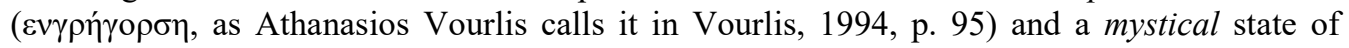
introversion, without encouraging the showy side of the ritual or cheesy tunes. The great proportion of litanies in the ecphonetic, recitative style (to which one may add the Great Responses and many other responses) is an element that impresses on the liturgy this dynamic, alert and at the same time mystical mood. 
koinonikon you either sing in the choir or you utter the prayer Kúple I $\eta \sigma o v ́$

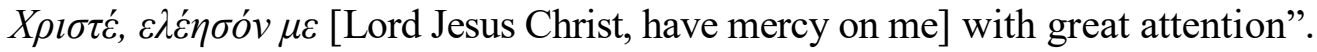

In the same vein, the Byzantium scholar Georgios Konstantinou is of the opinion that replacing the koinonikon with shorter chants, troparia, etc. is risky: "These replacement chants have no support. It is the moment of the koinonikon, no other chant is suited there. Other chants are used only because the psaltes do not know how to sing communion chants. We saw how the Athonite fathers perceive the liturgical and spiritual role of the koinonikon. They prepare for the Holy Eucharist. Picture all the people taking part in the service starting to pay their respects to the icons, to get ready for the communion. Even the people who do not wish to commune follow the same impressive ritual. We cannot experience this in a secular environment. It plays an important liturgical role! A special preparation mood is created. This is the purpose of the koinonikon. And this also explains the role of the kratema" 22 .

Consequently, the communion chant should not and cannot be replaced by other chants with the sole purpose of "animating" or "not boring" the people. We cannot "reform" the liturgy because of the psaltes" lack of training. Often, the cantors' education is deprived of investments (not only financial, but

\footnotetext{
${ }^{22}$ Additionally, here are some other important answers in which M. Konstantinou stresses the importance of the koinonikon (private discussion):

Question: What do you think about the solution proposed by M. Foundoulis that the psalm engendering the koinonikon should be sung instead when the choir cannot interpret a communion chant?
}

Answer: I do agree with it, but it must remain an exception and not become a rule. The psaltis must necessarily sing the cherubikon, and in the exact same fashion he is also compelled to chant the koinonikon.

Q: Should the koinonikon continue while the believers receive the communion?

A: Either it continues, or the $\Sigma \tilde{\omega} \mu \alpha X \rho \imath \sigma \tau o \tilde{v} \mu \varepsilon \tau \alpha \lambda \dot{\alpha} \beta \varepsilon \tau \varepsilon$ should be sung instead if the first koinonikon has ended. Some monasteries are in the habit of chanting the text of the koinonikon as a song that they afterwards repeat adding a second voice according to harmonic principles. These chants diminish the spirit of the koinonikon, even if, for instance, the katabasia would be also sung in extenso.

Q: In many parishes prayers are read now before the communion. Does this happen at Mount Athos as well?

A: Yes, it is customary to do that in Greece as well. But many also read thanksgiving prayers (after the Eucharist) when the koinonikon should be chanted, and this is wrong. It is just as unnatural for the priest to preach when the koinonikon should normally be chanted.

Q: In the Monasteries of Mount Athos is the koinonikon sung by a soloist or by the entire choir?

A: It depends on the monastery. If there are only a few monks living there... Even at Vatopaidi Monastery, where there are enough hieromonks and psaltes, the choir often empties because the fathers leave it long enough before the moment to go and venerate the icons, according to a well-established order. The entire moment gets very dynamic, the believers start moving around the church venerating the icons, as an integral part of a long vigil. Everything has its role and importance. 
also as far as the image and the "institution" of the psaltis are concerned). An incorrect, modest performance of the choir should make the priests react and invest all available means in order to correct and embellish the chanting. Often, the choir is the "first label" of a parish, the "first impression" offered to parishioners and passers-by, because, from all the arts embellishing a church, it has the most direct impact on the human soul. A beautiful painting or iconostasis cannot "compensate" for a negligent, out-of-tune, or simplistic chant.

\section{The need for a collection of old koinonika in Romanian}

In the Romanian principalities, as far as the psaltic art is concerned, the early $19^{\text {th }}$ century is marked by both the Chrysanthic reform (Constantinople, 1814), which was immediately implemented here with the help of the clergymen and the musicians of that time, and the first printed editions of psaltic music scores (See also Bălan, Lista cronologică).

Looking back at the Romanian printed editions which also include communion chants, chronologically, the first works of this kind belong to Nectarie Frimu (1846), who edits koinonika by Petros Lampadarios, Daniel the Protopsaltis, Petros Byzantios, Georgios the Cretan, Constantinos the Protopsaltis, Gregorios the Protopsaltis and Chourmouzios Chartophylax.

Not before long Anton Pann publishes his Heruvico-chinonicar [Collection of Cherubika and Koinonika]. The first volume (Pann, 1847a) encompasses three series of communion chants: the first comprises his own compositions, the second is made up of short versions of Dionysios Fotino's pieces, and the third includes short versions of Petros Byzantios' works. The second volume (Pann, 1847b) comprises Romanian adaptations of communion chants by Petros Lampadarios, Daniel the Protopsaltis, Dionysios Fotino, Iakobos the Protopsaltis, Georgios the Cretan, Petros the Byzantine and Chourmouzios Chartophylax.

In 1856, Seraphim the Hieromonk publishes a Liturghier [Liturgy Chants] comprising "communion chants for the entire year and Lent from the Liturgy of Saint Basil the Great and from the Liturgy of Saint Gregory the Great" (Serafim, 1856).

In 1873, Oprea Demetrescu edits a Liturghier comprising several weekly

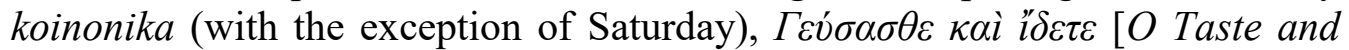
see] and a Sunday koinonikon.

Ioan Zmeu edits the work Utrenier şi Liturghier [Matins and Liturgy services] (the first edition dates from 1892), which includes Petros Lampadarios' weekly koinonika adapted into Romanian by Nectarie Frimu, Daniel the Protopsaltis' Sunday koinonika (First and Plagal of the First, Plagal of the Second, Plagal of the Fourth, and varis) and feast koinonika by Daniel the Protopsaltis, Petros Lampadarios and Gregory Lampadarios adapted by 
Ghelasie the Bessarabian. Communion chants are also present in the printings of Ștefanache Popescu.

This impressive editorial activity shows that the editors were trying to meet the need of publishing koinonika that had been previously recorded in the pages of musical manuscripts. Thus, the first printed editions promote works by $18^{\text {th }}$ and $19^{\text {th }}$-century composers as well as some new Romanian creations that carry on the spirit of the psaltic tradition.

Early $18^{\text {th }}$-century Romanian psaltic manuscripts in the Chrysanthic notation reveal a preference, at that time, for composers such as Petros Lampadarios, Daniel the Protopsaltis, Gregorios the Protopsaltis, Chourmouzios, Constantinos the Protopsaltis, Petros the Byzantine or Dionysios Fotino. These composers (out of whom Daniel was given a prominent place in the Neamţ manuscripts) represent, therefore, the classical standard of Byzantine composition, as there are no older compositions with which they could be compared. As a result, in the absence of the exegeses of older koinonika from the $13^{\text {th }}-17^{\text {th }}$ centuries $^{23}$ (produced by Chourmouzios and preserved in the manuscripts archived in the Greek National Library), the notion of classical style refers only to the works of more recent composers.

Macarie the Hieromonk emphasizes the differences that distinguished Ioannis and Daniel the Protopsaltes' works from the classical repertoire. He becomes even more explicit in this respect when he mentions Petros Lampadarios, whom he calls "a very clever and knowledgeable man" but of whom he says that "he strayed a little from the ways of the old" and that he "sowed" outside matters "in his lessons". Thus, Macarie left us an objective analysis of the evolution of compositional style in church music, showing an evident preference for the classical element represented by Koukouzelis, Chrysaphes, Balasios, Petros Bereketis, etc. Even if Macarie's interpretations focused mainly on the works of more recent composers (Petros Lampadarios, Daniel and Ioannis, Petros the Byzantine, Chourmouzios and Gregory), "in agreement with the developments taking place in the Greek world" (Moisil, 2016, p. 14), he also tried to promote classical, reference works (Petros Bereketis, Balasios the Priest, Germanos Neon Patron, Iakobos the Protopsaltis, Georgios the Cretan, Filothei sin Agăi Jipei ${ }^{24}$, Mihalache the Moldowallachian, Șărban the Protopsaltis, Radu the Protopsaltis, Arsenios the Vatopedian, Damian the Vatopedian and others). A proof in this respect are his collections of chants (most of them still unpublished), such as Stihirarul [Sticherarion], Papadichia [Papadike], Irmologhion Calofonicon [Eirmologion

\footnotetext{
23 Some of the koinonika transcribed by Chourmouzios Chartophylax are attributed, by tradition, to John of Damascus $\left(7^{\text {th }}-8^{\text {th }}\right.$ century).

${ }^{24}$ On Macarie's exegeses of $18^{\text {th }}$-century Romanian composers see also Bălan, 2013, pp. 5494.
} 
Kalophonikon], Pricesniarul ${ }^{25}$ [Collection of koinonika] or Anthologia [Anthology]. Thus Macarie is the last Romanian composer and interpreter to have shownan interest in promoting chants composed before Ioannis and Daniel, and alongside Visarion the Confessor he is the last promoter of the chants written in the newly embellished sticheraric style.

After Ioan Popescu-Pasărea's generation, Romanian editors have gradually given up this compositional genre, a phenomenon which reflects a general tendency among Romanian church choirs; there emerge replacement chants, most of them using the syntomos dromos or a moderate (argosyntomo) one, psalms, cherubika, verse chants, praises and, sometimes, the psaltic chants are even harmonized for two or three voices (fig. 4).

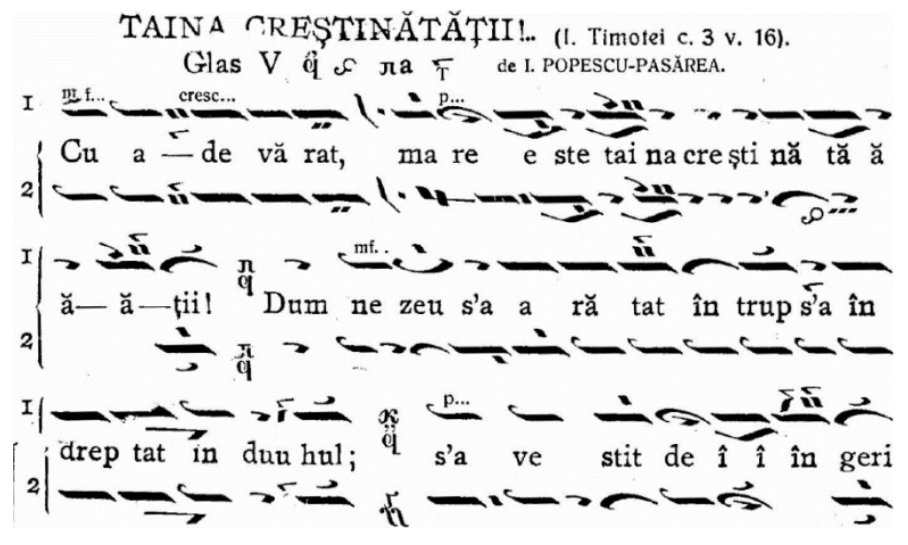

As early as the reign of Al. I. Cuza, choral performances are strongly encouraged so that the mixed choirs from many urban parishes have gradually developed a repertoire made up of various choral works (named „concertos”), devoted especially to the moment of the koinonikon.

We are witnessing a major shift, which is also reflected by musical editions. Koinonika or cherubika are no longer presented as complete portions of the Octoechos, but in an incomplete fashion, according to the editor's preferences. Extended chants are gradually replaced; the cherubikon is the "last redoubt", but it is already half-conquered by new compositions which also encourage the removal of some tones of the church Octoechos, such as the chromatic ones, the Fourth, or the Plagal of the Third ${ }^{26}$. The new cherubika, much shorter in length, which destroy the classical forms of the theseis, have been taking hold, as the church choir practice prefers repeating the same line

\footnotetext{
${ }^{25}$ On the contents of the unpublished collections, see Popescu, 1908, pp. 81-92.

${ }^{26}$ As a matter of fact, tones such as the Fourth, or the Papadic Plagal of the Third are rarely heard in church choirs nowadays.
} 


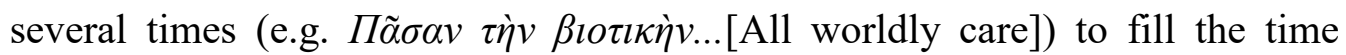
needed for the priest's ritual ${ }^{27}$. Naturally, the clerics turn against extended chants and the aforementioned modes, performed, in all likelihood, clumsily by psaltes who, in turn, cannot profit from an oral tradition that has been damaged by anti-ecclesiastical reforms. This chain of weaknesses has led to the establishment of a repertoire simple enough to be chanted by all the believers. In rural areas, the new psaltic repertoire simplified and harmonized by IoanPopescu Pasărea (and strongly encouraged by authorities through very large print-runs) encourages the creation of children's choirs that have been gradually replacing professional psaltes. Deprived of the fine execution of attractions and micro-intervals, the modes become major and minor scales ${ }^{28}$ and thus a "standardized" type of chanting is born as an open door to harmonic singing. Musical tastes have been going through a process of intense "Westernisation" which has advanced hand in hand with the dilution of choir models and the anti-ecclesiastical political and social reforms launched by Al. I. Cuza and continued during communism.

In recent years, the ever increasing interest of the younger generations of Romanian psaltes has led to a renewal of the Psaltic Art, not only at the interpretive, but also at the editorial level, through new editions or translations. The effort to adapt into Romanian the old masters' koinonika transcribed and interpreted by Chourmouzios Chartophylax is part of the same trend. The book - to be launched this spring in Iași with the blessing of His Eminence, the Most Reverend Father Theophanes, the Metropolitan of Moldova and Bukovina - is the first publication through which the masterpieces of the old teachers transcribed by Chourmouzios Chartophylax "are reborn" in the Romanian language ${ }^{29}$.

\section{Conclusions}

The koinonikon is one of the compositional instantiations of the Byzantine melos which should not be given up in liturgical practice, despite the "tastes of the time". Most of the liturgical repertoire is characterised by a specific dynamic which is meant to showcase the chanted texts and to engage the audience in a state of mind and soul "alertness", but some pieces, like the koinonikon or the cherubikon, are meant to "suspend" the listener's mind in a state of jubilation high above the words of the liturgy. The latter require a higher level of musical knowledge and vocal virtuosity and, above all, the

\footnotetext{
${ }^{27}$ Paradoxically, since the old cherubika covered the entire duration of this ritual.

${ }^{28}$ Indeed, psaltic music grammars from the early $19^{\text {th }}$ century describe diatonic tones as major or minor scales.

${ }^{29}$ This text was translated from Romanian into English by Sorina Postolea.
} 
collective capacity to turn to meditation and introversion - which is challenging indeed.

Liturgical practice allowed us to observe that older communion chants are sometimes more successful than those of newer authors in capturing this "appeasement", meditation mood, precisely because they remain more faithful to their formulaic nature. It is this feature that confers to these melodies the quality of sound archetypes, which, no matter how original, do not alienate the classic melodic formulae.

Almost all the ample compositions in Romanian printings are signed by late $18^{\text {th }}$ or $19^{\text {th }}$-century authors, so these composers ended up being considered "classics", even if their works were never compared to those by earlier composers (on the other hand, it goes without saying that this period is a truly "classic" one in light of the unfortunate innovations that emerged in it especially in the late $19^{\text {th }}$ century).

A comparison with koinonika from the $13-18^{\text {th }}$ centuries (Chourmouzios Chartophylax' exegeses kept in autograph manuscripts at the National Library of Greece) reveals a series of differences at the compositional level between various ages, and some trends which, starting from the $19^{\text {th }}$ century, no longer follow the old patterns to the letter. These stylistic phenomena have not been completely analysed yet through comparative studies which could contribute to a clearer definition of the term "classical", in the case of koinonika, at least. In conclusion, there is an acute need to revive psaltic art in Romania, in at least two directions: liturgical practice, which should preserve and guard musicalliturgical typikon, and printings, which should promote the classic repertoire above all.

\section{References}

\section{a. Manuscripts}

BAR 27820 (Lybrary of Romanian Academy)

МПТ 705 (National Library of Greece, "Metochion of Saint Sepulchre" Collection).

\section{b. Books}

Alexandru, Maria, Paleography Course III - course materials (unpublished). Thessaloniki: "Aristotelis" University.

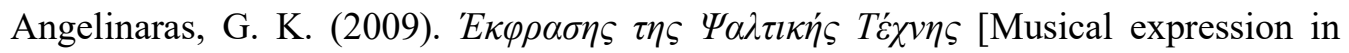
Psaltic Art]. Atena: Athos.

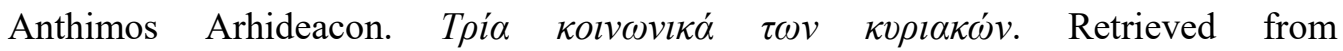
http://www/psalmodia.blogspot.gr. 
Asser, M. (Ed.) 2005. Psalter of the Prophet and King David - According to the Septuagint, $\quad$ England: $\quad$ Shrewsbury. Retrieved from http://www.orthodoxengland.org.uk/pdf/kjvsept.pdf

Bălan, F. Lista cronologică a cărţilor de muzică psaltică în limba română, tipărite în România intre 1820 şi 2014 [The chronologic list of the psaltic books edited in Romania between 1820 and 2014]. Retrieved from http://www.byzantion.ro/articole/176.html.

Bălan, F. (2013). Câteva exegeze în notație hrisantică ale Ieromonahului Macarie din Psaltichia Ieromonahului Filothei [Some exegeseis of Makarie the Hieromonk în chrysanthic notation from Filothei's Psaltichia]. In Simpozionul Internațional de Muzicologie Bizantină. 300 de ani de românire (1713 - 2013), 54-94. București: Editura Universității Naționale de Muzică.

Barbu-Bucur, S. (1992). Filothei sin Agăi Jipei. Psaltichie Rumânească. IV Stihirar Penticostar, seria Izvoare ale muzicii românești, VII D. București: Editura Episcopiei Buzăului.

Conomos, D. E. (1974). Byzantine Trisagia and Cherubika of the Fourteenth and Fifteenth Centuries. A study in Late Byzantine Liturgical Chant. Thessaloniki.

Conomos, D. E. (1985a). The Late Byzantine and Slavonic Communion Cycle: Liturgy and Music. Washington: Dumbarton Oaks Research Library and Collection.

Conomos, D. E. (Ed.) (1985b). The treatise of Manuel Chrysaphes, the Lampadarios: on the Theory of the Art of Chanting and on Certain Erroneus Views That Some Hold About it, colectia Monumenta Musicae Byzantinae, seria Corpus Scriptorum de Re Musica. Viena: VÖAW.

Foundoulis, I. (2009). Dialoguri liturgice [Liturgical dialogues] III, translated into Romanian by Sabin Preda. București: Editura Bizantină.

Gheorghiță, N. (2009). Chinonicul duminical în perioada postbizantină (1453-1821) [The Sunday Koinonikon during the Post-Byzantine Age (1453-1821)]. București: Sophia.

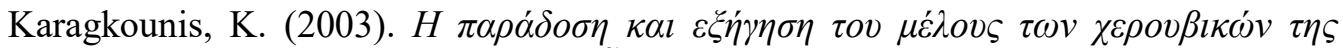
$\beta v \zeta \alpha v \tau \imath v \eta \dot{\varsigma} \kappa \alpha l \mu \varepsilon \tau \alpha \beta v \zeta \alpha v \tau \imath v \eta \dot{s} \mu \varepsilon \lambda o \pi o l i \tilde{\alpha}$. Athens: Centre of Byzantine Musicology.

Macarie the Hieromonk (1823). Irmologhion sau Catavasieriu musicesc. Wien.

Moisil, C. (2016). Geniu românesc vs. tradiție bizantină [Romanian genius vs. Byzantine tradition]. București: Editura Muzicală.

Nectarie Frimu. (1846). Carte de cântări bisericești, traduse din originalurile grecești în limba Moldovinească și dată la lumină acum întâiaș dată în zilele ocârmuirii prealuminatului şi preaînălțatului nostru Domn, Mihail Grigoriu Sturza Voievod, tome I and II, Neamt,

Pann, A. (1847a). Heruvico-chinonicar care cuprinde în sine trei rînduri heruvice şi chinonice duminicale pe toate glasurile, afară de ale săptămînii, lîngă care s-au adăugat şi axioane 22 [Collection of Cherubika and Koinonika which includes three 
series of Cherubika and Koinonika in all tones, with the exception of the weekly ones, to which 22 axions were also added], I. Bucureşti.

Pann, A. (1847b). Heruvico-chinonicar anual care cuprinde în sine deosebite heruvice şi chinonice pentru toate sărbătorile anului, lingă care s-au adăugat şi antiaxioanele lor [Collection of Cherubika and Koinonika which includes Cherubika and Koinonika for all the feasts in the year, to which their anti-axions were also added], II. Bucureşti.

Popescu, N. M. (1908). Viața și activitatea dascălului de cântări Macarie Ieromonahul [The Life and work of the music teacher Macarie the Hieromonk]. București: Instit. de Arte Grafice Carol Göbl.

Popescu-Pasărea, Ioan. (1925). Liturghierul de strană. București.

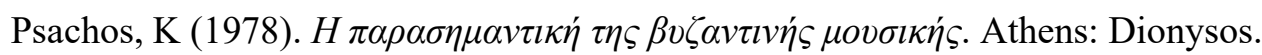

Serafim Ieromonahul (1856) Rînduiala Sfintei şi Dumnezeieştii Liturghii care cuprinde în sine: Binecuvintează şi celelalte antifoane, heruvicele, axioanele şi chinonicele de peste tot anul şi ale Postului Mare de la Liturghia Sfintului Vasile şi de la Liturghia mai-nainte sfinţită a Sfintului Grigorie Dialogul, [The Service of the Divine and Holy Liturgy which includes: Bless the Lord and the other antiphons, cherubika, axions and koinonika for the entire year and for Lent from the Liturgy of Saint Basil the Great and the Liturgy of Saint Gregory the Great] II. Buzău.

Stathis, G. (1998). $H \varepsilon \xi \xi \eta \dot{\gamma} \eta \sigma \eta \tau \eta \varsigma ~ \pi \alpha \lambda \alpha l \alpha \dot{\varsigma} \beta v \zeta \alpha v \tau \imath v \eta \dot{\varsigma} \sigma \eta \mu \varepsilon l o \gamma \rho \alpha \varphi i ́ \alpha \varsigma$, Athens: Institute of Byzantine Musicology.

Troelsgård, C. (2001). "Koinōnikon". In Stanley Sadie \& John Tyrrell (Ed.), New Grove Dictionary of Music and Musicians, XIII. London: Oxford University Press, second edition.

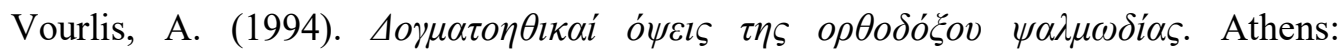
Koultoura. 